\title{
Glycated Serum Albumin Induces Interleukin-6 Expression in Vascular Smooth Muscle Cells
}

\author{
Seung-\| Baek, Byung-Yong Rhim and Koanhoi Kim*
}

Department of Pharmacology, School of Medicine-Pusan National University, Yangsan 626-770, Korea

Received November 12, 2010 / Accepted January 10, 2011

\begin{abstract}
Diabetes mellitus is associated with vascular complications. Diabetic patients exhibit high levels of glycated adducts in serum compared to non-diabetic individuals. The aim of this study was to investigate whether extracellular glycated albumin (GA) predisposes vascular smooth muscle cells (VSMCs) to pro-inflammatory phenotype. Exposure of rat aortic smooth muscle cells (AoSMCs) to GA not only enhanced interleukin-6 (IL-6) release but also activated promoter activity of the IL-6 gene. GA-induced IL-6 promoter activation was suppressed by dominant-negative forms of Toll-like receptor (TLR)- 4 and myeloid differentiation factor 88 (MyD88), but not by dominant-negative-forms of TLR-2 and TIR-domain-containing adapter-inducing interferon- $\beta$ (TRIF). Extracellular signal-regulated kinase (ERK) inhibition and diphenyleneiodium (DPI) also attenuated IL-6 induction by GA. Mutation at the nuclear factor- $\mathrm{kB}(\mathrm{NF}-\mathrm{\kappa B})$-binding site in the IL-6 promoter region suppressed promoter activation in response to GA. The present study proposes that GA would contribute to inflammatory reaction in the stressed vasculature by inducing IL-6 in VSMCs, and that TLR-4, EKR, and NF-KB play active roles in the process.
\end{abstract}

Key words : Interleukin-6 (IL-6), glycated serum albumin, vascular smooth muscle cells

\section{Introduction}

Hyperglycemia is related to the development of chronic clinical complications associated with diabetes mellitus, including retinopathy, neuropathy, nephropathy, and angiopathy $[2,23]$. The non- enzymatic condensation of free glucose with reactive lysine amino groups in albumin results in the formation of Schiff base intermediates that undergo Amadori rearrangement to form stable protein-glucose adducts. The early-stage reaction products of albumin or serum proteins are called Amadori-modified (glycated) albumin, or fructosamines. Through further oxidative and non-oxidative reactions, Amadori-modified products form advanced glycation end products (AGEs) $[3,13]$. The fact that elevated concentration of Amadori-modified albumin promotes generalized vasculopathy in animal models indicates that AGEs are likely to accumulate in the vessel wall, where they can disrupt cell structure and function $[4,5]$.

Amadori adducts are able to modulate vascular cells. In vascular smooth muscle cells (VSMCs), glycated albumin (GA) stimulates proliferation via extracellular signal-regulated kinase (ERK) and protein kinase C (PKC); promotes

*Corresponding author

Tel : +82-51-510-8064, Fax : +82-51-510-8068

E-mail : koanhoi@pusan.ac.kr nitric oxide (NO) production by increasing inducible nitric oxide synthase (iNOS) expression through transcriptional activation of the iNOS gene; and induces CCL-2 and interleukin (IL)-6 expression via p38 mitogen-activated protein kinase (MAPK) $[9,10]$. In human umbilical vein endothelial cells, GA induces E-selectin expression through NADPH oxidase activation and apoptosis through enhancement of iNOS activity [12]. The effects of GA on cells are likely to be mediated via receptor pathways. GA binds to cells in a dose-responsive and saturable manner [22,25]. GA is recognized as a bifunctional ligand with a plasma membrane site that binds glucose residues and another distinct plasmalemmal vesicle site that binds albumin domains; a calnexin-like protein has been reported to selectively bind fructosyl-lysine residues in glucose-modified albumin in mesangial cells [26].

VSMCs play a pivotal role in regulation of vascular tone in the media of healthy arteries. In atherosclerosis, VSMCs undergo phenotypic and cellular changes thought to be crucial in the development of atherosclerotic plaques, and thus produce cytokines and excessive extracellular matrix proteins $[16,17,21]$. Activation of Toll-like receptors (TLRs), which are a family of pattern-recognition receptors, triggers a downstream signaling cascade, leading to activation of the nuclear factor- $\mathrm{kB}(\mathrm{NF}-\mathrm{kB})$ pathway, which then activates the transcription of genes that encode pro-inflammatory mole- 
cules, including cytokines, chemokines, and other effectors of the innate immune response [19,32]. TLRs are able to change VSMCs to a pro-inflammatory phenotype, resulting in induction of cytokines and chemokines like IL-6 and CXCL8 (also known as IL-8) [29,30]. Since IL-6 expression is significantly elevated in patients with type 2 diabetes [11], it was hypothesized that the Amadori adduct would contribute to vasculopathy by inducing IL-6 via certain types of receptors.

To explore the potential role of glycation in vascular inflammation, it was investigated whether GA induced IL-6 in VSMCs and found that rat aortic smooth muscle cells (AoSMCs) exhibited IL-6 up-regulation via transcriptional activation in response to GA. Furthermore, the involvement of TLRs and transcription elements in GA-induced IL-6 up-regulation in VSMCs was investigated.

\section{Materials and Methods}

\section{Cell culture and reagents}

A7r5 rat AoSMCs were purchased from the American Type Culture Collection (Manassas, VA) and cultured in Dulbecco's modified Eagle's medium-high glucose (DMEM) supplemented with $10 \%$ fetal bovine serum (FBS), 50 units $/ \mathrm{ml}$ penicillin and $50 \mathrm{\mu g} / \mathrm{ml}$ streptomycin in a humidified atmosphere of $5 \% \mathrm{CO}_{2}$. Glycated human serum albumin, N-acetylcysteine (NAC) and diphenyleneiodium (DPI) were purchased from Sigma-Aldrich (St. Louis, MO). The reporter plasmid containing a 651-bp fragment of the IL-6 gene promoter region (pIL-6-Luc) located directly upstream of the transcriptional start site, as well as its mutant constructs were kindly provided by Dr. Oliver Eickelberg [8]. Dominant-negative mitogen-activated kinase kinase (MKK3) (Y193A) and MKK4 (S257A,T261A) were kindly provided by Dr. Roger J. Davis [6]. Dominant-negative MKK1 (K97M) was from Dr. Natalie G. Ahn [18]. Plasmids encoding dominant-negative forms of TLR pathway were purchased from Invivogen (San Diego, CA).

\section{Enzyme linked immunosorbent assay (ELISA) of IL-6}

The amount of IL- 6 released from the cells into the culture medium was determined using a commercially available ELISA kit according to the manufacturer's instructions (Amersham, Piscataway, NJ). Cells were serum-starved for $6 \mathrm{hr}$ and exposed to GA prior to isolation of the culture medium. The isolated culture medium and IL-6 standards were added to a plate pre-coated with a monoclonal antibody against IL-6. After incubation for an hour, the plate was washed and incubated with an enzyme-linked polyclonal antibody specific for IL-6. After several washes, the substrate solution was added, and the color intensity was determined.

Reverse transcription (RT) - polymerase chain reaction (PCR)

Total RNAs extracted from VSMCs were reverse-transcribed for an hour at $42^{\circ} \mathrm{C}$ with Moloney Murine Leukemia Virus reverse transcriptase, followed by PCR analysis. For PCR analysis, primers for IL-6 were 5'-AGTTGCCTTCTTG GGACTGA-3' (forward) and 5'-CAGAATTGCCATTGCACA AC-3' (reverse). Products were size-separated by electrophoresis on $2 \%$ agarose gels and visualized after staining with ethidium bromide.

\section{Transient transfection and luciferase assay}

Rat AoSMCs were seeded in 100-mm culture dishes 24 $\mathrm{hr}$ before transfection. Cells were transfected with $10 \mu \mathrm{g}$ IL-6 reporter plasmid and $3 \mu \mathrm{g} \beta$-galactosidase plasmid using Lipofectamine (Invitrogen, Carlsbad, CA). Cells were then re-fed DMEM containing 10\% FBS $6 \mathrm{hr}$ post-transfection and incubated overnight. Transfected cells were exposed to 1 $\mathrm{mg} / \mathrm{m}$ GA for the indicated time periods after serum starvation. Luciferase activity was measured using a luciferase assay kit (Promega, Madison, WI) with signal detection in a luminometer and normalized to $\beta$-galactosidase activity.

\section{Statistics}

Statistical analyses were performed by ANOVA, and $p<$ 0.05 was considered to be statistically significant.

\section{Results}

The effects of GA on IL-6 transcript and protein in VSMCs

To investigate the effects of GA on IL-6 expression in VSMCs, the level of IL- 6 transcript was examined by RT-PCR after exposure of rat AoSMCs to GA. IL-6 transcript was elevated in the presence GA. The elevation was observed as early as $6 \mathrm{hr}$ post-treatment and persisted up to $24 \mathrm{hr}$ after treatment (Fig. 1A). IL-6 release from VSMCs was also examined by ELISA. The amount of IL- 6 in the medium increased from 95 to $460 \mathrm{pg} / \mathrm{ml}$ in the presence of GA (Fig. 
(A)

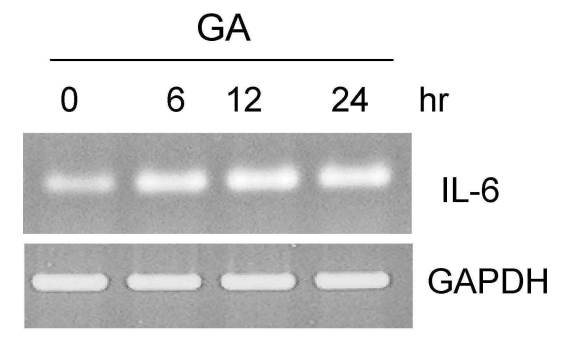

(B)
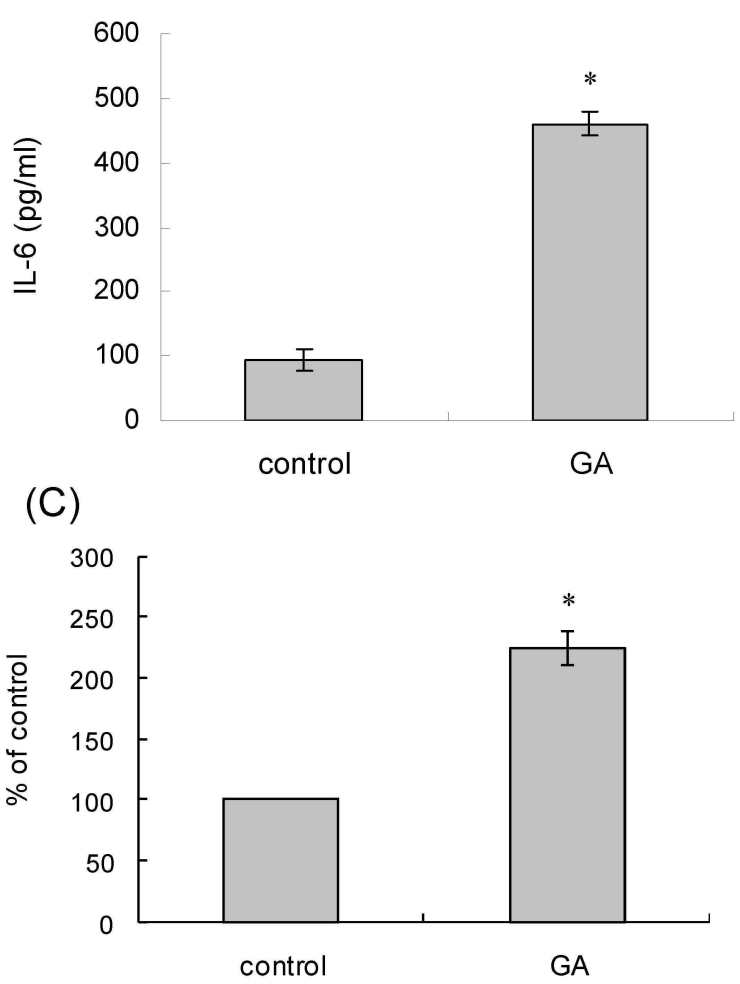

Fig. 1. The effect of GA on IL-6 expression. (A) Rat AoSMCs were treated for the indicated time periods with 1 $\mathrm{mg} / \mathrm{ml}$ of GA, and IL- 6 transcript was amplified by RT-PCR. PCR products were separated on agarose gels and visualized. (B) Rat AoSMCs $\left(1 \times 10^{6}\right.$ cells) cultured in growth media were incubated for $12 \mathrm{hr}$ in the presence of BSA (control) or GA $(1 \mathrm{mg} / \mathrm{ml})$. After the culture media were harvested, IL- 6 secreted into the culture medium was measured using ELISA. Data are expressed as mean $\pm \mathrm{SD}$ ( $\mathrm{n}=3$ replicates/group). ${ }^{*} p<0.001$ vs. control. (C) Rat AoSMCs were transfected with the pIL-6-Luc construct and incubated in the presence of BSA (control) or GA ( $1 \mathrm{mg} / \mathrm{ml}$, for $12 \mathrm{hr}$ ). Luciferase activity was determined and normalized to $\beta$-galactosidase activity. Induction was calculated relative to the activity of control cells. Data are expressed as mean \pm SD ( $n=3$ replicates/group). ${ }^{*} \not<0.01$ vs. control.

1B). Reporter gene assay was carried out to investigate whether GA increased IL-6 transcript via activation of IL6 gene promoter. Rat AoSMCs were transfected with the IL-6 reporter plasmid, and luciferase activity was assessed in the presence or absence of GA. Compared with control exposed to BSA, GA increased luciferase activity by 1.9 -fold, indicating that GA promoted IL-6 transcriptional activity (Fig. 1C).

\section{Involvement of TLR-4 pathways in $\| \mathrm{L}-6$ promoter activation}

To investigate roles of TLRs in GA-induced promoter activation of IL-6 gene, a reporter gene assay was carried out after transfection of rat AoSMCs with the IL-6 reporter plasmid in combination with dominant-negative forms in TLR pathways. The GA-induced luciferase activity driven by IL-6 promoter was affected by co-transfection with dominant-negative forms of TLR-4 (Fig. 2A) and myeloid differentiation factor 88 (MyD88) (Fig. 2B). Of the two, dominant-negative MyD88 profoundly inhibited promoter activation of IL-6 gene. Co-transfection with dominant negative forms of TLR-2 and TIR-domain-containing adapter-inducing interferon- $\beta$ (TRIF), however, did not inhibit GA-induced IL- 6 gene activation.

\section{Roles of MAPKs in GA-induced $\|-6$ promoter activation in VSMCs}

To understand the roles of MAPK in GA-induced IL-6 promoter activation, plasmids encoding dominant negative forms of MKK were employed. Dominant negative forms of MKK1, MKK3, or MKK4 were co-transfected into rat aortic smooth muscle cells, and luciferase activity was assessed after stimulation with GA (Fig. 3A). Luciferase activity was significantly decreased by co-transfection with MKK1(K97M). Cotransfection with MKK3(A) and MKK4(A) GA-induced IL-6 promoter activity. Next, the effects of inhibitors of ERK1/2, p38 MAPK, and JNK on IL-6 promoter activation were examined. Rat were transfected with the IL-6 reporter plasmid and pretreated with the inhibitors U0126 (an ERK1/2 kinase inhibitor), SB202190 (a p38 MAPK inhibitor), or SP600125 (a JNK inhibitor) before stimulation with GA (Fig. 3B). hereas SB202190

\section{Roles of $\mathrm{NF}-\mathrm{kB}$ and $\mathrm{C} / \mathrm{EBP}$ in $\mathrm{GA}$-induced $\| \mathrm{L}-6$ promoter activation in VSMCs}

To investigate roles of the transcription elements in GA-induced IL-6 promoter activation, reporter gene assays were carried out after transfection of rat AoSMCs with an IL-6 reporter plasmid mutated at the nuclear factor (NF)- $\mathrm{kB}-$, 
(A)

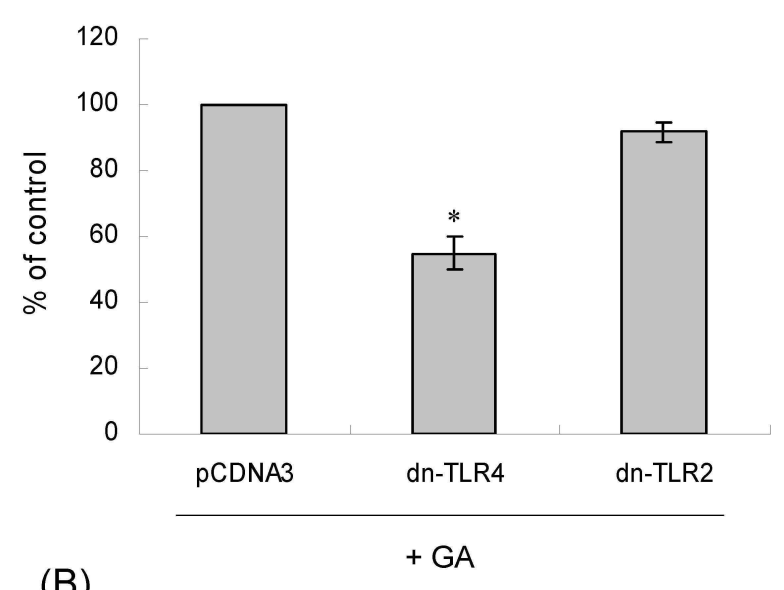

(B)

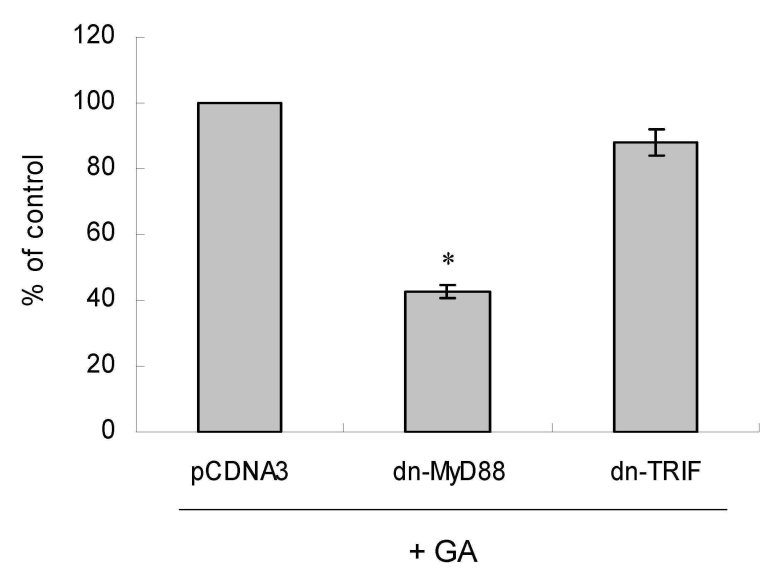

Fig. 2. Involvement of TLR-4 in GA-induced IL-6 gene activation. (A) The IL-6-Luc plasmid was co-transfected into rat AoSMCs with the indicated dominant-negative forms of TLRs (dn-TLR4 and dn-TLR2) or control vector (pCDNA3). After stimulation with GA $(1 \mathrm{mg} / \mathrm{ml}$, for $12 \mathrm{hr}$ ), luciferase activity was determined and normalized to $\beta$-galactosidase activity. The luciferase activity obtained from pCDNA3-transfected cells were considered $100 \%$, and the luciferase activity of cells transfected with dominant negative TLRs was calculated relative to it. Data are expressed as mean $\pm \mathrm{SD}(\mathrm{n}=3$ replicates/group). ${ }^{*} p<0.01$ vs. pCDNA3. (B) The IL-6-Luc plasmid was co-transfected into rat AoSMCs with the dominant negative forms of MyD88 (dn-MyD88) and TRIF (dn-TRIF) or control vector (pCDNA3). After stimulation with GA $(1 \mathrm{mg} / \mathrm{ml}$, for $12 \mathrm{hr})$, luciferase activity was determined and normalized to $\beta$-galactosidase activity. The luciferase activity obtained from pCDNA3-transfected cells were considered $100 \%$, and the luciferase activity of cells transfected with the dominant negative forms was calculated relative to it. Data are expressed as mean $\pm \mathrm{SD}$ ( $\mathrm{n}=3$ replicates/group). ${ }^{*} p<0.01$ vs. pCDNA3.
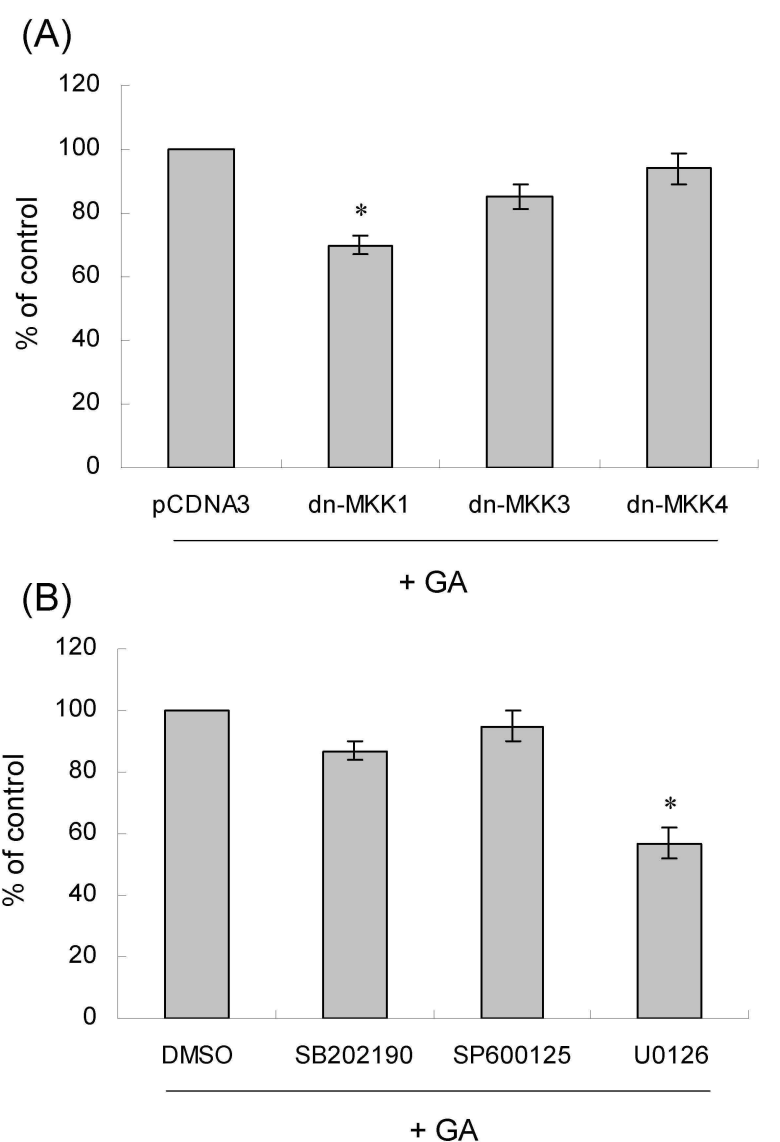

Fig. 3. The effects of MAPKs inhibitors on GA-induced IL-6 expression. (A) The IL-6 reporter plasmid was co-transfected into rat AoSMCs with the indicated dominant-negative form of MKK (dn-MKK), respectively. The transfected cells were stimulated GA $(1 \mathrm{mg} / \mathrm{ml}$, for $12 \mathrm{hr}$ ) and processed for luciferase assay. Induction was calculated relative to the activity of the cells that were co-transfected with a control plasmid (pCDNA3). Data are expressed as mean $\pm S D$ ( $n=3$ replicates/group). ${ }^{*} p<0.05$ vs. pCDNA3. (B) Rat AoSMCs transfected with the wild-type pIL-6-Luc651 construct, pretreated with SB202190, SP600125, or U0126 (10 mM each for $2 \mathrm{hr}$ ), stimulated with GA $(1 \mathrm{mg} / \mathrm{ml}$, for $12 \mathrm{hr})$ and processed for luciferase assay. Induction was expressed relative to the activity of the cells that were stimulated with GA in the presence of dimethylsulfoxide (DMSO), the carrier of the inhibitors. Data are expressed as mean $\pm \mathrm{SD}(\mathrm{n}=3$ replicates/group). ${ }^{*} p<0.01$ vs. DMSO.

activating protein-1 (AP-1)- or CCAAT-enhancer-binding protein (C/EBP)-binding site (Fig. 4). GA significantly increased luciferase activity. Mutation at the NF- $\kappa B$ binding site profoundly inhibited the luciferase activity induced by GA. Mutation at the AP-1- or C/EBP-binding site did not change promoter activation. 


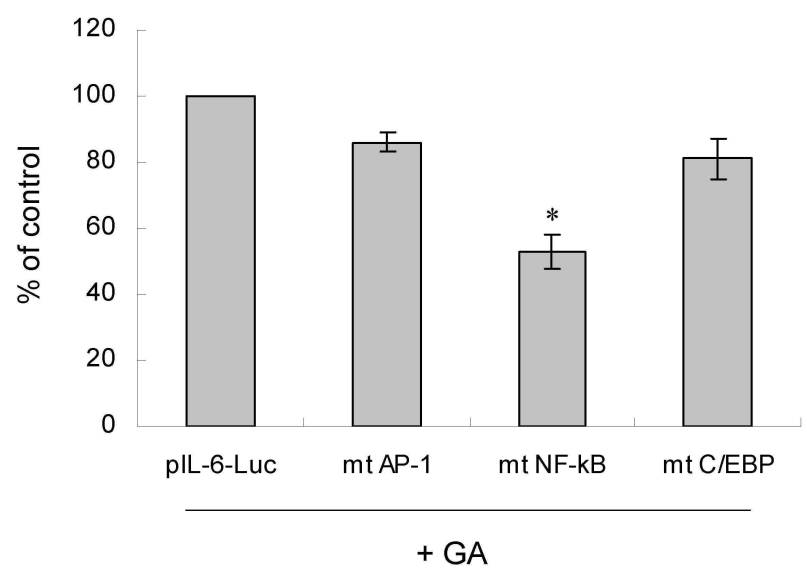

Fig. 4. Involvement of transcriptional elements in GA-induced IL-6 gene activation. Rat AoSMCs were transfected with the wild-type pIL-6-Luc construct or the indicated mutant constructs of AP-1, NF-kB, and C/EBP, respectively. Cells were stimulated with GA $(1 \mathrm{mg} / \mathrm{ml}$, for $12 \mathrm{hr})$ and processed for luciferase and $\beta$-galactosidase assays. Induction was calculated relative to the activity of cells transfected with wild-type IL-6 promoter (pIL-6-Luc). Data are expressed as mean $\pm \mathrm{SD}$ ( $\mathrm{n}=3$ replicates/group). ${ }^{*} p<0.01$ vs. pIL-6-Luc.

Roles of reactive oxygen species (ROS) in GA-induced IL-6 promoter activation in VSMCs

The effects of the two ROS quenchers, NAC and DPI, on GA-induced IL-6 up-regulation were investigated by reporter gene assay (Fig. 5A). Of the two ROS quenchers, DPI affected IL-6 induction. It profoundly inhibited GA-induced promoter activation of the IL- 6 gene by $30 \%$. NAC, however, showed trivial effects on GA-induced promoter activation of IL- 6 gene. It was investigated whether NAC and DPI affected secretion of IL-6 protein by ELISA (Fig. 5B). GA-mediated IL-6 secretion was inhibited in the presence of DPI. NAC, however, did not affect IL-6 secretion.

\section{Discussion}

Expression of cytokine or chemokine in vasculature contributes to vascular diseases. It is believed that cytokine- and chemokine-mediated inflammatory and immune process including immigration and infiltration of leukocytes, macrophages and $\mathrm{T}$ cells into and activation of them within the artery leads to progression of atherosclerosis and plaque instability. The specialized roles of cytokines or chemokines in atherosclerosis are well documented [17,31]. Owing to active participation of chemokine in atherogenesis, the identification and characterization of the factors regulating chemo-
(A)
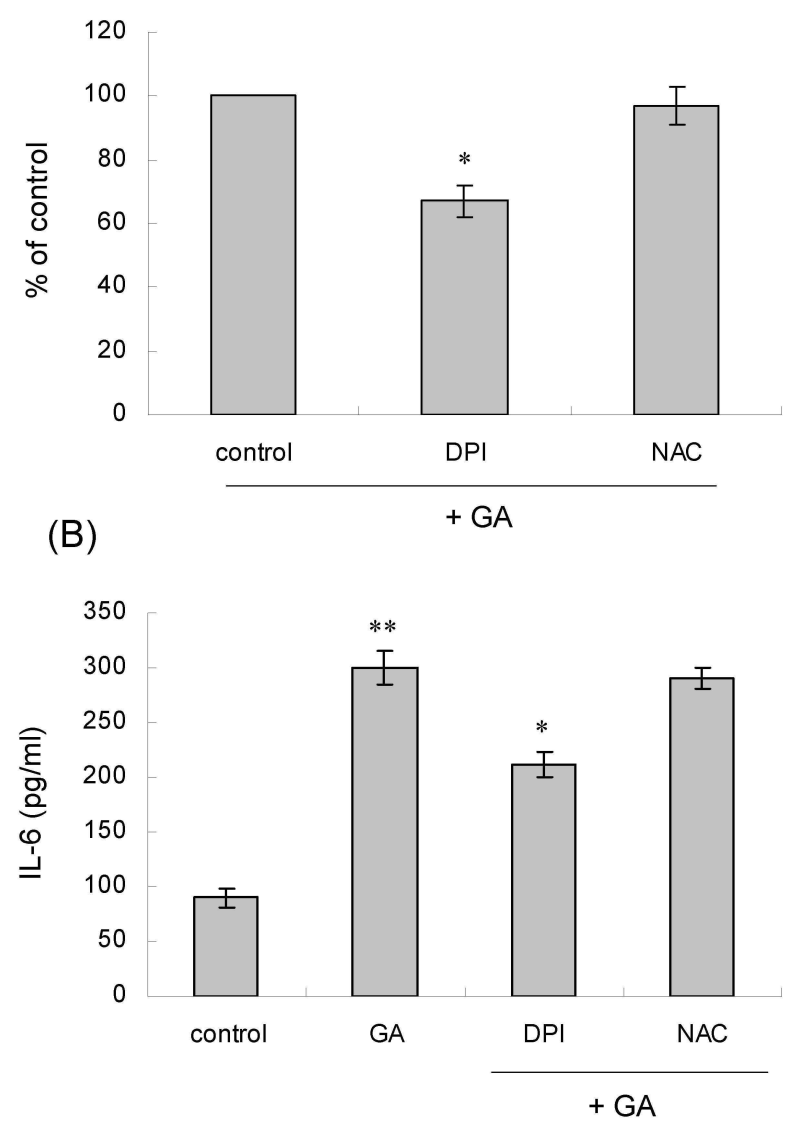

Fig. 5. The effects of NAC and DPI on GA-induced IL-6 expression. (A) Rat AoSMCs were transfected with wild-type pIL6-Luc construct and stimulated with GA $(1 \mathrm{mg} / \mathrm{ml}$, for $12 \mathrm{hr}$ ) after pre-incubation for $30 \mathrm{~min}$ with $(10 \mu \mathrm{M})$ or NAC $(5 \mathrm{mM})$. Promoter activation is expressed relative to the luciferase activity of GA alone. Data are expressed as means $\pm \mathrm{SD}$ ( $\mathrm{n}=3$ replicates/group). ${ }^{*} \not<0.05$ vs. GA. (B) After pre-treatment for $30 \mathrm{~min}$ with DPI or NAC, rat AoSMCs were stimulated with GA (1 $\mathrm{mg} / \mathrm{ml}$, for $12 \mathrm{hr}$ ). The amount of secreted IL-6 into the medium was measured by ELISA. Data are expressed as means $\pm \mathrm{SD}$ ( $\mathrm{n}=3$ replicates/group). ${ }^{* *} p<0.01$ vs. control. ${ }^{*} p<0.05$ vs. GA.

kine expression are important and will lead us to new insights into strategies for the prevention and therapy of atherosclerosis.

The present study focused on the expression of IL- 6 and regulation of IL-6 gene in AoSMCs in response to extracellular GA. When VSMCs were exposed to GA, IL-6 transcript was significantly increased, and luciferase activity driven by the IL- 6 gene promoter was elevated, which indicates that extracellular GA transactivates IL-6 gene. 
Moreover, GA enhanced release of IL-6 protein from VSMCs. Taken together, these data indicate that GA up-regulates IL-6 at transcriptional and post-translational levels.

The association of TLRs with vascular diseases has been demonstrated. Compared with normal arteries, expression of TLRs, such TLR-1, -2 , and -4 , is markedly enhanced, and a considerable proportion of TLR-expressing cells are activated in the human atherosclerotic lesion [7]. Among the subtypes of TLRs, TLR-4 seems to be closely associated with atherosclerosis, as knockout of TLR-4 or its adaptor molecule, MyD88, has been reported to block inflammatory response and proliferation of VSMCs in the atherosclerotic lesion $[14,20]$. Among the subtypes of TLRs, expression of -4 has been detected in human VSMCs [28,30]. TLR-4, which is the most abundant TLR in human VSMCs, transmits signals through MyD88-dependent and -independent (e.g., via TRIF) pathways after recognition of lipopolysaccharide (LPS), an exogenous ligand [1,15]. When the roles of the TLRs in GA-mediated activation of IL-6 gene were examined using dominant-negative constructs, IL-6 promoter activity was attenuated by dominant-negative TLR-4 and MyD88, but not by dominant-negative TLR-3, TRIF, indicating major roles of TLR-4 and MyD88 in activation of IL-6 gene by GA. Taken together, these findings indicate that GA is likely to induce IL-6 expression in VSMCs via MyD88-dependent TLR-4 pathway.

The IL-6 promoter region contains transcription element of NF-kB, C/EBP, and AP-1 [27]. Thus, it was determined which transcription elements were responsible for promoter activation in response to GA using mutant IL-6 reporter plasmids. The mutation at NF- $\kappa B$-binding site significantly attenuated promoter activity, indicating active role of NF- $\kappa B$ in IL-6 induction. This finding agrees with the fact that the signal from TLR-4 activates NF- $\kappa B$ [1,15].

ROS play a role in TLR-4 signaling. In human VSMCs, LPS enhances the stability of TLR-4 mRNA, as well as the phosphorylation of MAPKs in a NADPH oxidase-mediated, ROS-dependent manner [24]. Therefore, participation of ROS in IL-6 induction was investigated using DPI, a NADPH oxidase inhibitor, and NAC, a ROS scavenger. DPI inhibited promoter activation of IL- 6 gene, and prevented release of the IL- 6 protein in response to GA. These findings indicate involvement of NADPH oxidase-mediated ROS in GA-mediated IL-6 expression.

The present study has demonstrated that GA induces IL-6 expression through various cellular factors such as MAPKs,
NF- $k B$, and TLR-4. These findings suggest that GA can up-regulate IL-6 in VSMCs via the aforementioned molecules, and thereby contribute to vasculopathy in patients with diabetes.

\section{Acknowledgement}

This work was supported for two years by Pusan National University Research Grant (K. Kim).

\section{References}

1. Akira, S. and K. Takeda. 2004. Toll-like receptor signalling. Nat. Rev. Immunol. 4, 499-511.

2. Brownlee, M. 2001. Biochemistry and molecular cell biology of diabetic complications. Nature 414, 813-820.

3. Bunn, H. F., K. H. Gabbay, and P. M. Gallop. 1978. The glycosylation of hemoglobin: relevance to diabetes mellitus. Science 200, 21-27.

4. Clements, R. S., Jr., W. G. Robison, Jr., and M. P. Cohen. 1998. Anti-glycated albumin therapy ameliorates early retinal microvascular pathology in $\mathrm{db} / \mathrm{db}$ mice. J. Diabetes Complications 12, 28-33.

5. Cohen, M. P., R. S. Clements, J. A. Cohen, and C. W. Shearman. 1996. Glycated albumin promotes a generalized vasculopathy in the $\mathrm{db} / \mathrm{db}$ mouse. Biochem Biophys. Res. Commun. 218, 72-75.

6. Derijard, B., J. Raingeaud, T. Barrett, I. H. Wu, J. Han, R. J. Ulevitch, and R. J. Davis. 1995. Independent human MAP-kinase signal transduction pathways defined by MEK and MKK isoforms. Science 267, 682-685.

7. Edfeldt, K., J. Swedenborg, G. K. Hansson, and Z. Q. Yan. 2002. Expression of toll-like receptors in human atherosclerotic lesions: a possible pathway for plaque activation. Circulation 105, 1158-1161.

8. Eickelberg, O., M. Roth, R. Mussmann, J. J. Rudiger, M. Tamm, A. P. Perruchoud, and L. H. Block. 1999. Calcium channel blockers activate the interleukin- 6 gene via the transcription factors NF-IL6 and NF-kappaB in primary human vascular smooth muscle cells. Circulation 99, 2276-2282.

9. Hattori, Y., H. Kakishita, K. Akimoto, M. Matsumura, and K. Kasai. 2001. Glycated serum albumin-induced vascular smooth muscle cell proliferation through activation of the mitogen-activated protein kinase/extracellular signal-regulated kinase pathway by protein kinase C. Biochem Biophys. Res. Commun. 281, 891-896.

10. Hattori, Y., M. Suzuki, S. Hattori, and K. Kasai. 2002. Vascular smooth muscle cell activation by glycated albumin (Amadori adducts). Hypertension 39, 22-28.

11. Herder, C., B. Haastert, S. Muller-Scholze, W. Koenig, B. Thorand, R. Holle, H. E. Wichmann, W. A. Scherbaum, S. Martin, and H. Kolb. 2005. Association of systemic chemokine concentrations with impaired glucose tolerance and 
type 2 diabetes: results from the Cooperative Health Research in the Region of Augsburg Survey S4 (KORA S4). Diabetes 54, S11-17.

12. Higai, K., A. Shimamura, and K. Matsumoto. 2006. Amadori-modified glycated albumin predominantly induces E-selectin expression on human umbilical vein endothelial cells through NADPH oxidase activation. Clin. Chim Acta. 367, 137-143.

13. Higgins, P. J. and H. F. Bunn. 1981. Kinetic analysis of the nonenzymatic glycosylation of hemoglobin. J. Biol. Chem. 256, 5204-5208.

14. Hollestelle, S. C., M. R. De Vries, J. K. Van Keulen, A. H. Schoneveld, A. Vink, C. F. Strijder, B. J. Van Middelaar, G. Pasterkamp, P. H. Quax, and D. P. De Kleijn. 2004. Toll-like receptor 4 is involved in outward arterial remodeling. Circulation 109, 393-398.

15. Kawai, T. and S. Akira. 2005. Toll-like receptor downstream signaling. Arthritis Res. Ther. 7, 12-19.

16. Libby, P. 2002. Inflammation in atherosclerosis. Nature 420, 868-874.

17. Libby, P., P. M. Ridker, and A. Maseri. 2002. Inflammation and atherosclerosis. Circulation 105, 1135-1143.

18. Mansour, S. J., W. T. Matten, A. S. Hermann, J. M. Candia, S. Rong, K. Fukasawa, G. F. Vande Woude, and N. G. Ahn. 1994. Transformation of mammalian cells by constitutively active MAP kinase. Science 265, 966-970.

19. Medzhitov, R. 2001. Toll-like receptors and innate immunity. Nat. Rev. Immund. 1, 135-145.

20. Michelsen, K. S., M. H. Wong, P. K. Shah, W. Zhang, J. Yano, T. M. Doherty, S. Akira, T. B. Rajavashisth, and M. Arditi. 2004. Lack of Toll-like receptor 4 or myeloid differentiation factor 88 reduces atherosclerosis and alters plaque phenotype in mice deficient in apolipoprotein E. Proc. Natl. Acad Sci. U.S.A. 101, 10679-10684.

21. Ross, R. 1986. The pathogenesis of atherosclerosis-an update. N. Engl. J. Med 314, 488-500.

22. Salazar, R., R. Brandt, and S. Krantz. 1995. Expression of fructosyllysine receptors on human monocytes and monocyte-like cell lines. Biochim Biophys. Acta. 1266, 57-63.

23. Singh, R., A. Barden, T. Mori, and L. Beilin. 2001. Advanced glycation end-products: a review. Diabetologia 44, 129-146.
24. Sun, H. N., S. U. Kim, M. S. Lee, S. K. Kim, J. M. Kim, M. Yim, D. Y. Yu, and D. S. Lee. 2008. Nicotinamide adenine dinucleotide phosphate (NADPH) oxidase-dependent activation of phosphoinositide 3-kinase and p38 mitogenactivated protein kinase signal pathways is required for lipopolysaccharide-induced microglial phagocytosis. Biol. Pharm Bull. 31, 1711-1715.

25. $\mathrm{Wu}, \mathrm{V}$. Y. and M. P. Cohen. 1995. Evidence for a ligand receptor system mediating the biologic effects of glycated albumin in glomerular mesangial cells. Biochem Biophys. Res. Commun. 207, 521-528.

26. Wu, V. Y., C. W. Shearman, and M. P. Cohen. 2001. Identification of calnexin as a binding protein for Amadori-modified glycated albumin. Biochem Biophys. Res. Commun. 284, 602-606.

27. Wu, Y. M., D. R. Robinson, and H. J. Kung. 2004. Signal pathways in up-regulation of chemokines by tyrosine kinase MER/NYK in prostate cancer cells. Cancer Res. 64, 7311-7320.

28. Yang, X., D. Coriolan, V. Murthy, K. Schultz, D. T. Golenbock, and D. Beasley. 2005. Proinflammatory phenotype of vascular smooth muscle cells: role of efficient Toll-like receptor 4 signaling. Am J. Physiol. Heart Circ. Physiol. 289, H1069-1076.

29. Yang, X., D. Coriolan, K. Schultz, D. T. Golenbock, and D. Beasley. 2005b. Toll-like receptor 2 mediates persistent chemokine release by Chlamydia pneumoniae-infected vascular smooth muscle cells. Arterioscler. Thromb. Vasc. Biol. 25, 2308-2314.

30. Yang, X., V. Murthy, K. Schultz, J. B. Tatro, K. A. Fitzgerald, and D. Beasley. 2006. Toll-like receptor 3 signaling evokes a proinflammatory and proliferative phenotype in human vascular smooth muscle cells. Am J. Physiol. Heart Circ Physiol. 291, H2334-2343.

31. Zernecke, A., E. Shagdarsuren, and C. Weber. 2008. Chemokines in atherosclerosis: an update. Arterioscler. Thromb. Vasc. Biol. 28, 1897-1908.

32. Zuany-Amorim, C., J. Hastewell, and C. Walker. 2002. Toll-like receptors as potential therapeutic targets for multiple diseases. Nat. Rev. Drug Discov. 1, 797-807. 


\section{초록 : 혈관평활근세포에서 glycated albumin에 의한 interleukin-6 증가에 관여하는 인자에 대한 연구}

백승일 · 임병용 · 김관회*

(부산대학교 의학전문대학원 약리학교실)

Glycate화된 단백질이 혈관질환의 발생에 관여하는지 알아보기 위하여 glycated albumin (GA)이 혈관평활근 세포에서 인터루킨-6 발현에 영향을 주는지 조사하고 또한 그 기전을 구명하였다. GA에 노출된 혈관평활근세포 에서 인터루킨-6 transcript가 증가하고, 인터루킨-6 단백질의 분비가 증가하고, 또한 인터루킨-6 유전자의 promoter가 활성화되었다. GA에 의한 인터루킨-6 유전자의 promoter 활성화는 dominant negative 형태의 Toll-like receptor (TLR)-4와 myeloid differentiation factor 88 (Myd88)에 의하여 크게 감소되었지만, dominant negative 형태의 TLR-2와 TIR-domain-containing adapter-inducing interferon- $\beta$ (TRIF)의 영향을 받지 않았다. 그리고 Extrcellular signal-related kinase (ERK) 억제 물질들은 GA에 의한 인터루킨-6의 분비 및 인터루킨-6 유전자 promoter 활성화를 억제하였다. 그리고 인터루킨-6 유전자의 promoter의 NF-kB-binding sequence에 변이는 GA에 의한 인터루킨-6 유전자의 promoter 활성화 억제하였다. 이러한 결과는 혈관평활근세포에서 GA에 의한 인터루 킨-6 유전자 활성화에 TLR-4와 ERK 및 NF-kB가 관여함을 의미한다. 